\title{
Die Dhechff(prectiung
}

\section{Sex \\ Qbexlandesgexichte auf dem (Gebiefe des Givilredifs.}

\author{
\$erausigegeben bon

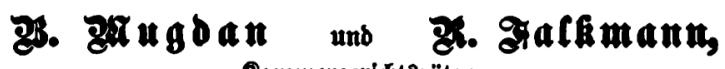

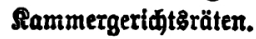

\section{Glftex \$and.}

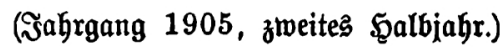

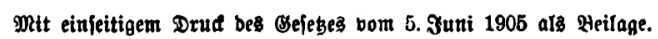

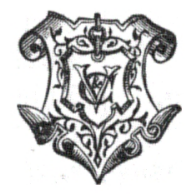

Seipzig,

Berlag von Beit \& Eomp.

1905 